\title{
Alpha7 Nicotinic Acetylcholine Receptors Modulate Motivation to Self-Administer Nicotine: Implications for Smoking and Schizophrenia
}

\author{
Darlene H Brunzell*, I and J Michael Mclntosh ${ }^{2,3}$ \\ 'Department of Pharmacology and Toxicology, Interdisciplinary Neuroscience Program and Institute for Drug and Alcohol Studies, Virginia \\ Commonwealth University School of Medicine, Richmond, VA, USA; ${ }^{2}$ Department of Psychiatry, University of Utah, Salt Lake City, UT, USA; \\ ${ }^{3}$ Department of Biology, University of Utah, Salt Lake City, UT, USA
}

\begin{abstract}
Individuals diagnosed with schizophrenia have an exceptionally high risk for tobacco dependence. Postmortem studies show that these individuals have significant reductions in $\alpha 7$ nicotinic acetylcholine receptors (nAChRs) in several brain areas. Decreased $\alpha 7$-mediated function might not only be linked to schizophrenia but also to increased tobacco consumption. The purpose of this study was to determine whether pharmacological blockade of $\alpha 7 \mathrm{nAChRs}$ would increase motivation of rats to intravenously self-administer nicotine ( NIC) during a progressive ratio schedule of reinforcement (PR). Before PR, rats received local infusions of 0, 10 , or 20 pmol of a selective $\alpha 7$ nAChR antagonist, $\alpha$-conotoxin ArlB [VIIL,VI6D] (ArlB) into the nucleus accumbens (NAc) shell or the anterior cingulate cortex, brain areas that contribute to motivation for drug reward. We additionally sought to determine whether local infusion of 0 , 10 , or $40 \mathrm{nmol}$ of a selective $\alpha 7 \mathrm{nAChR}$ agonist, PNU 282987, into these brain areas would decrease motivation for NIC use. Infusion of ArlB into the NAc shell and anterior cingulate cortex resulted in a significant increase in active lever pressing, breakpoints, and NIC intake, suggesting that a decrease in $\alpha 7$ nAChR function increases motivation to work for NIC. In contrast, PNU 282987 infusion resulted in reductions in these measures when administered into the NAc shell, but had no effect after administration into the anterior cingulate cortex. These data identify reduction of $\alpha 7 \mathrm{nAChR}$ function as a potential mechanism for elevated tobacco use in schizophrenia and also identify activation of $\alpha 7 \mathrm{nAChRs}$ as a potential strategy for tobacco cessation therapy.

Neuropsychopharmacology (20 I2) 37, I |34-I I43; doi:I0.1038/npp.20 I I.299; published online I4 December 20 I I
\end{abstract}

Keywords: $\alpha 7$; motivation; nicotine; smoking; tobacco; schizophrenia

\section{INTRODUCTION}

Individuals with schizophrenia have a high risk for tobacco dependence. Epidemiological studies estimate that as many as $80 \%$ of individuals diagnosed with schizophrenia smoke cigarettes and clinical reports indicate that those with schizophrenia are particularly heavy smokers (Hughes et al, 1986; Glassman, 1993; Olincy et al, 1997; Kalman et al, 2005; Tidey et al, 2005; Williams et al, 2005, 2007; McKee et al, 2009). In support of a self-medication hypothesis, some studies have shown that smoking enhances cognition, improves sensory-gating deficits, and relieves side effects of neuroleptic therapeutics (Leonard et al, 1998, 2007; Sacco

* Correspondence: Dr DH Brunzell, Department of Pharmacology and Toxicology, Interdisciplinary Neuroscience Program and Institute for Drug and Alcohol Studies, Virginia Commonwealth University School of Medicine, 410 N. 12th Street, PO Box 9806I3, Richmond, VA 23298, USA, Tel: + I 804628 7584, Fax: + I 8048282117 , E-mail: dbrunzell@vcu.edu

Received 30 June 2011; revised 14 October 2011; accepted 31 October 2011 et al, 2005; Levin and Rezvani, 2007; D'Souza and Markou, 2011). Another equally plausible hypothesis is that these individuals have a shared vulnerability for schizophrenia and tobacco dependence.

An accumulation of genetic reports have identified polymorphisms linked to the $\alpha 7$ nicotinic acetylcholine receptor (nAChR) gene with diagnosis of schizophrenia (Leonard et al, 1996; Freedman et al, 1997; Stassen et al, 2000; Stephens et al, 2009; Mexal et al, 2010). Recent reports suggest that genetic variations in CHRNA7 may be associated with tobacco dependence as well (De Luca et al, 2004; Saccone et al, 2010). Nicotine (NIC), a major psychoactive ingredient in tobacco, binds to these ion channel receptors that are activated endogenously by the neurotransmitter, acetylcholine (ACh). Postmortem studies indicate that individuals with schizophrenia have marked reductions of $\alpha 7$ nAChRs in several brain areas, including the hippocampus and cingulate cortex (Freedman et al, 1995; Leonard et al, 1996, 1998, 2000; Guan et al, 1999; Court et al, 2000; Marutle et al, 2001; Mexal et al, 2010). Several CHRNA7 polymorphisms may contribute to a 
smoking phenotype in otherwise healthy subjects (Saccone et al, 2010), and independent data sets have revealed CHRNA7 polymorphisms associated with increased vulnerability for a tobacco dependence phenotype in those with schizophrenia diagnosis (De Luca et al, 2004). $\alpha 7$ Polymorphisms are linked to sensory-gating deficits (Freedman et al, 1997), a phenomenon commonly observed with schizophrenia diagnosis. Rodent studies have indicated that sensory-gating deficits may be due to a reduction in $\alpha 7$ nAChR function (Luntz-Leybman et al, 1992; Stevens et al, 1996, 1998; Hajos et al, 2005). Although no studies to date have correlated genetic analyses with $\alpha 7 \mathrm{nAChR}$ expression in humans, in vitro studies show that point mutations in the CHRNA7 promoter region and in an $\alpha 7$-duplicated gene is sufficient to alter $\alpha 7 \mathrm{nAChR}$ function (Leonard et al, 2002; Araud et al, 2011; de Lucas-Cerrillo et al, 2011).

The purpose of this preclinical study was to determine whether reductions of the $\alpha 7 \mathrm{nAChR}$ function constitute a biological mechanism for increased motivation for tobacco use as measured using a progressive ratio schedule of reinforcement $(\mathrm{PR})$ during NIC self-administration in rats. Rats, like humans, readily self-administer NIC and there is 93\% sequence homology in the rat and human $\alpha 7$ nAChRs (as determined using the Basic Local Alignment Search Tool for accession numbers AAB25224-rat and AAB40114human) (Séguéla et al, 1993; Elliott et al, 1996). During $\mathrm{PR}$, rats must work increasingly hard for a single delivery of NIC until they give up responding (ie, reach their breakpoint). We tested the hypothesis that reduced activity of $\alpha 7$ nAChRs in areas that regulate motivation for drug use would result in an increase in active lever pressing for NIC and breakpoints during PR. Such an effect might contribute to increased tobacco addiction in those with schizophrenia. The selective $\alpha 7 \mathrm{nAChR}$ antagonist, $\alpha$-conotoxin ArIB [V11L,V16D] (ArIB) (Whiteaker et al, 2007) was infused into the nucleus accumbens (NAc) shell or anterior cingulate cortex immediately before PR. This study also questioned whether local infusion of a selective agonist of $\alpha 7$ nAChRs, PNU 282987 (Bodnar et al, 2005), into the NAc shell and anterior cingulate cortex would lead to reductions in responding maintained by NIC during PR. The $\alpha 7$ agonists are currently being explored as therapeutics to improve cognition, working memory, and sensory-gating deficits in schizophrenia (Bodnar et al, 2005; Olincy et al, 2006; Bitner et al, 2007; Freedman et al, 2008; Rezvani et al, 2009; Thomsen et al, 2009; Hajos and Rogers, 2010; Castner et al, 2011; Marquis et al, 2011). A positive finding would have implications for smoking cessation therapies in general.

\section{MATERIALS AND METHODS}

\section{Animals}

A total of 34, adult, male, Long-Evans rats (Harlan Laboratories, Dublin, VA) were used for these studies. Rats were individually housed in a temperature- and humiditycontrolled vivarium under a 12/12 h light/dark cycle (lights on at 0600 hours). Behavioral testing took place between 1300 and 1900 hours. Rats weighed $\sim 300 \mathrm{~g}$ upon arrival and began testing at $320 \mathrm{~g}$. This body weight was maintained by daily food rations throughout behavioral testing.
Experimental protocols were approved by the Institutional Animal Care and Use Committee at the Virginia Commonwealth University and were in accordance with the Guidelines for the Care and Use of Laboratory Animals, as set forth by the National Institutes of Health.

\section{Drug Dosing and Administration}

During self-administration procedures, rats received $0.03 \mathrm{mg} / \mathrm{kg} /$ i.v. infusion of NIC (by weight of freebase) in $0.0533 \mathrm{ml}$ delivered over $1 \mathrm{~s}$. NIC hydrogen tartrate salt was dissolved in $0.9 \%$ sterile saline and stored in the dark to prevent degradation. $\alpha$-CTX ArIB [V11L,V16D] was synthesized as described previously (Whiteaker et al, 2007) (Institute for Behavioral Genetics, Boulder, CO) and dissolved in $0.9 \%$ sterile saline. PNU 282987 was obtained commercially (Tocris, Ellisville, MO) and dissolved according to the supplier's recommendations in $100 \mathrm{mM} \mathrm{HCl}$ sterile saline. Aliquots were stored at $-20{ }^{\circ} \mathrm{C}$ and thawed immediately before use. Immediately before $\mathrm{PR}$ testing, intra-accumbens shell or intra-anterior cingulate infusions of 0,10 , or $20 \mathrm{pmol} / \mathrm{h}$ emisphere of ArIB, or 0,10 or $40 \mathrm{nmol} /$ hemisphere PNU 282987 were administered at a volume of $0.5-1.0 \mu \mathrm{l}$ at a rate no greater than $0.5 \mu \mathrm{l} / \mathrm{min}$ using a within-subject, Latin-square design across days. Vehicle infusions were administered intermittently to assure drug clearance. Animals either received infusions into the anterior cingulate cortex or the NAc, and separate animals were used in experiments that assessed the effects of $\alpha 7$ $\mathrm{nAChR}$ antagonist and agonist.

\section{Intra-Cranial Guide Cannula Implantations}

All surgeries were performed using aseptic procedures under isoflurane anesthesia (induced at $3.5 \mathrm{l} / \mathrm{min}$ of oxygen and $3.5 \%$ isoflurane gas and maintained at $\sim 2.51 / \mathrm{min}$ of oxygen and $2.0-2.75 \%$ isoflurane). During surgery, rats received $5 \mathrm{mg} / \mathrm{kg}$ i.p. carprofen for preemptive analgesia. Surgical areas were shaved and cleaned with $7.5 \%$ povidone-iodine and $70 \%$ reagent alcohol. Rats were placed in a stereotaxic device with the bregma and lambda leveled to within $0.05 \mathrm{~mm}$. Animals were implanted with 22-G bilateral guide cannula (Plastics One, Roanoke, VA) targeting either the NAc shell $(+1.6 \mathrm{~mm}$ anterior, $\pm 0.75 \mathrm{~mm}$ from midline, $-6.5 \mathrm{~mm}$ ventral from the bregma) or the anterior cingulate cortex $(+1.8$ anterior, \pm 0.75 from midline, -2.75 ventral from the bregma). Guide cannulae were held in place with dental cement anchored with jeweler's screws, and dummy cannulae were inserted into the guides to maintain patency. Rats received $64 \mathrm{mg}$ acetaminophen mixed in wet chow for 3 days after surgery. After behavioral procedures, brains were harvested to assess cannulae placement.

\section{Intra-Jugular Catheter Implantation}

Animals were anesthetized, prepped for surgery, and received analgesia as described above. A polyurethane catheter (3.5 French, Access Technologies) was implanted in the right jugular vein above the atrium and passed subcutaneously to the rat's back where it was connected to a cannula connector pedestal (Plastics One) implanted 
posterior to the rat's scapulae. To prevent infection, all rats received s.c. injection of 75000 Units of penicillin G and $0.1 \mathrm{ml}$ intra-catheter injection of $0.031 \mathrm{mg} / \mathrm{ml}$ ticarcillin/ clavulanate in a $25 \%$ glycerol/heparinized saline solution (catheter lock). Rats were allowed to recover for at least 5 days before self-administration training. Before and after training sessions, catheters were irrigated with $0.9 \%$ sterile saline. Catheter patency was defined as a rapid loss of consciousness after $1.6 \mathrm{mg}$ i.v. ketamine infusion. In the case of catheter failure, the left jugular vein was catheterized and the animal was returned to the study.

\section{NIC Self-Administration}

Self-administration procedures were as described previously (Brunzell et al, 2010). All self-administration procedures occurred in MED Associates operant chambers located within sound-attenuating boxes (St Albans, VT). Rats were tethered to a stainless steel-encased infusion tubing that was suspended from the chamber ceiling (Plastics One) to enable them to move freely about the chamber during each $2 \mathrm{~h}$ self-administration session. Levers were extended and a 5-w house light remained illuminated during all behavioral procedures. For a period of at least 10 days, rats were reinforced under a fixed ratio 1 (FR1) schedule of reinforcement maintained by NIC. NIC infusions were delivered using a Model PHS-100 syringe pump located on the outside of each sound-attenuating box. A panel light above the active (right-side) lever and a Sonalert tone generator at the rear of the chamber operated as cues. For NIC rats, depression of the 'active' lever resulted in delivery of a $1 \mathrm{~s}, 0.03 \mathrm{mg} / \mathrm{kg} / \mathrm{i}$.v. NIC bolus plus a $20 \mathrm{~s} \mathrm{light}+$ tone. No further NIC was delivered during this time-out period. To control for potential locomotor effects of the $\alpha 7$ nAChR ligands and for the primary reinforcing properties of the cues, a separate group of rats received the same cues without NIC infusion upon depression of the active lever (CUEonly). Depressions of the 'inactive' left lever were recorded but were without scheduled consequences for NIC and CUEonly rats. Rats were trained for at least 10 days and until they reached a criterion of 3 consecutive days of $>70 \%$ active:total lever presses. Behavioral programs and data collection were controlled by MED-PC IV software (MED Associates).

\section{PR Responding Maintained by NIC}

After FR training, rats were reinforced using a PR schedule. This phase of training required that rats depress the lever an increasing number of times to obtain a single NIC infusion and/or cue reinforcement (eg, 1, 2, 4, 6, 9, 12, 15, 20, 25, 32, 40, 50, 62, 77, 95) (Arnold and Roberts, 1997). Sessions lasted for $2 \mathrm{~h}$ or until a rat failed to respond for 20 consecutive minutes. Active and inactive lever responses, number of infusions, and the highest lever depression criterion achieved (breakpoint) were recorded.

\section{Local Infusions of $\alpha 7$ Agonists and Antagonists into the Anterior Cingulate and NAc Shell}

Rats received $2-3$ days of $0.9 \%$ sterile saline infusions and intermittent infusions of vehicle to assure a stable level of
$\mathrm{PR}$ responding. Independent groups of rats received daily infusions of either ArIB $(0,10,20$ pmol/hemisphere; $n=18)$ or PNU $282987(0,10,40 \mathrm{nmol} /$ hemisphere; $n=16)$ using a within-subject, Latin-square counterbalanced delivery of doses. Implanted guide cannulae targeting the NAc shell or anterior cingulate cortex assured that ligands did not diffuse to brain areas dorsal to the desired brain regions (Brunzell et al, 2009, 2010). Infusions were made using a micro infusion pump with Hamilton syringes attached to PE 20 tubing (Braintree Scientific, Braintree, MA). Infusion volumes were no greater than $1 \mu \mathrm{l}$ and were delivered at a rate no faster than $0.5 \mu \mathrm{l} / \mathrm{min}$ through internal cannulae that extended $0.5 \mathrm{~mm}$ beyond the guides. Infusions were followed by a 2 min wait period to allow for drug diffusion and to prevent backflow of ArIB or PNU 282987 through the guide cannula.

\section{Statistical Analysis}

Within-subject, repeated-measures ANOVAs were used to analyze effects of vehicle and various concentrations of ArIB or PNU 282987 on behavioral measures for NIC and CUEonly rats during PR. Significant interactions of NIC condition with drug infusion were followed up with post hoc $t$-tests that compared behavioral data after drug infusion to data collected after infusion of vehicle into the brain areas studied.

\section{RESULTS}

Antagonism of NAc shell $\alpha 7 \mathrm{nAChRs}$ resulted in a dosedependent increase in motivation to self-administer NIC (Figure 1). There was a significant interaction of NIC condition with the ArIB dose for measures of breakpoint $\left(\mathrm{F}_{1,7}=8.26, p=0.02\right)$ and active lever pressing $\left(\mathrm{F}_{1,7}=9.56\right.$, $p=0.02$ ) revealing that this effect was specific to NIC animals. There were main effects of NIC treatment $\left(\mathrm{F}_{1,7}=92.077, p<0.01\right)$ and ArIB dosage $\left(\mathrm{F}_{1,7}=5.53\right.$, $p=0.05)$ for infusions/CUE presentations earned, but the interaction of these factors failed to reach significance. Post hoc $t$-tests showed that the $20 \mathrm{pmol} /$ hemisphere infusion led to significant increases in how hard animals were willing to work for NIC (Figure 1a and $b$ ) and in the amount of NIC infusions earned (Table 1$)$ ( $p$ 's $<0.05)$. Previous studies have shown that rodents will press for a visual stimulus reinforcer and that this behavior, like drug reinforcement, is dopamine mediated (Caggiula et al, 2002; Olsen and Winder, 2009). Infusion of ArIB into the NAc shell had no effect on lever pressing or breakpoints in CUEonly rats, suggesting that this effect did not generalize to other reinforcers. There was also no effect of drug exposure on response accuracy (active lever presses/(active + inactive lever presses)) after infusions of ArIB into the NAc shell $(\mathrm{F}<1.0)$; response accuracy remained high regardless of ArIB dose (Figure 1c), indicating that ArIB-associated increases in lever pressing were directed toward the lever that was reinforced with NIC infusions and not due to a non-specific increase in lever pressing activity.

Antagonism of $\alpha 7 \mathrm{nAChRs}$ in the anterior cingulate cortex of an independent group of rats resulted in similar increases in motivation to self-administer NIC. There was a 
a Nucleus Accumbens Shell
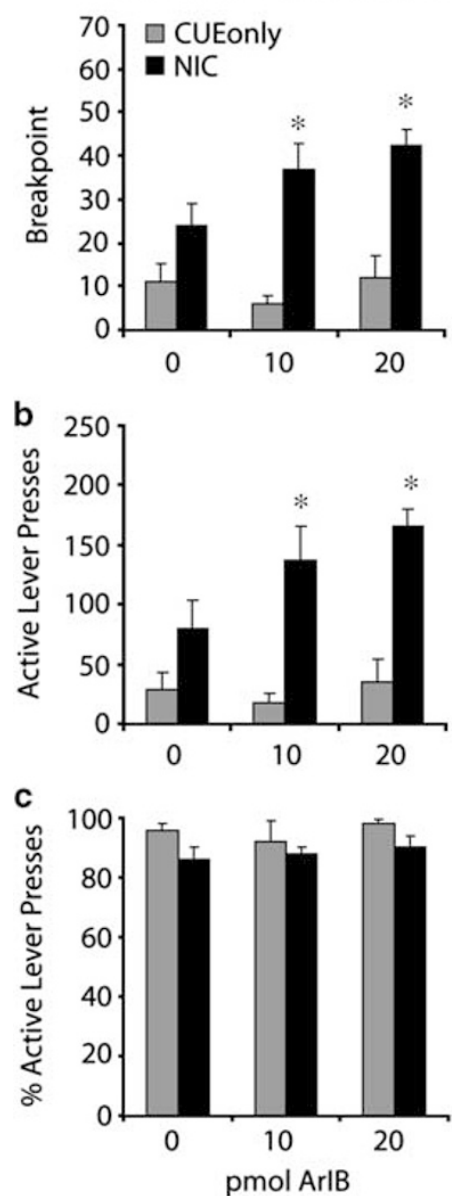

Figure I Antagonism of $\alpha 7 \mathrm{nAChRs}$ in the NAc shell increases motivation to self-administer nicotine. Local NAc shell infusion of ArlB led to a dose-dependent increase in (a) breakpoints and (b) active lever pressing maintained by nicotine during a progressive ratio schedule of reinforcement (NIC; $n=4)$. There was no effect of ArlB infusion on breakpoint or active lever pressing in rats reinforced with light + tone cues but no nicotine (CUEonly; $n=4$ ). (c) Response accuracy as measured by \% active lever pressing was not affected by NAc shell infusion of ArlB in NIC or CUEonly rats. *Significantly different from NIC vehicle infusion $(p<0.05)$. significant interaction of NIC condition with ArIB dose for breakpoint $\left(\mathrm{F}_{1,8}=10.77, p=0.01\right)$ and active lever pressing $\left(\mathrm{F}_{1,8}=8.53, p=0.02\right)$ and NIC infusions/CUE presentations $\left(\mathrm{F}_{1,8}=18.71, p<0.01\right)$. In comparison to vehicle infusion, local infusion of 10 or $20 \mathrm{pmol} /$ hemisphere of ArIB into the anterior cingulate cortex led to a significant increase in active lever pressing, breakpoints (Figure $2 \mathrm{a}$ and $\mathrm{b}$ ), and NIC/CUE delivery (Table 1) in NIC ( $p$ 's <0.05) but not CUEonly subjects. As with the NAc shell, there was no effect of ArIB infusion into the anterior cingulate on response accuracy (Figure $2 \mathrm{c}, \mathrm{F}<1.0$ ), suggesting that $\alpha 7 \mathrm{nAChRs}$ in this region do not modulate non-specific lever pressing activity or motivation to work for cue reinforcement. These findings support the hypothesis that reductions of the $\alpha 7$ nAChR function in the NAc shell and anterior cingulate cortex significantly increase motivation for NIC use.

The next series of experiments tested whether activation of $\alpha 7 \mathrm{nAChRs}$ in these brain regions would attenuate responding maintained by NIC during PR. Local infusion of the selective $\alpha 7 \mathrm{nAChR}$ agonist PNU 282987 into the NAc shell resulted in a significant interaction of NIC condition and drug dosage for breakpoint $\left(\mathrm{F}_{1,6}=13.80, p=0.01\right)$ for active lever pressing $\left(\mathrm{F}_{1,6}=33.19, p<0.01\right)$ and number of infusions/CUE presentations attained $\left(\mathrm{F}_{1,6}=6.82, p=0.04\right)$. In contrast to increases in active lever presses and breakpoints observed in rats after antagonism of the NAc shell $\alpha 7$ nAChRs, rats that received local activation of these nAChRs through infusion of PNU 282987 showed reductions in active lever presses and breakpoints during $\mathrm{PR}$ (Figure 3). NIC rats showed a significant reduction in active lever presses and breakpoints after intra-accumbens shell infusion of 10 or $40 \mathrm{nmol} /$ hemisphere of the PNU compound ( $p$ 's $<0.05$ ). As before, this effect was specific to NIC rats and not observed in CUEonly animals. There was also no effect of NIC condition or drug infusion on response accuracy $(\mathrm{F}<1.0)$.

In contrast to pretreatment with the $\alpha 7$ antagonist, ArIB, effects of PNU 282987 were specific to the NAc shell. There was no interaction of NIC condition with PNU 282987 concentration observed for measures of breakpoint, active lever presses, or number of NIC infusions $(\mathrm{F}<1.0)$ after anterior cingulate infusion of this selective

Table I Nicotine Intake after NAc Shell or Anterior Cingulate Infusion of $\alpha 7$ nAChR Antagonist or Agonist

\begin{tabular}{|c|c|c|c|c|c|c|c|}
\hline \multicolumn{5}{|c|}{$\alpha$-Conotoxin ArIB [VIIL, VI6D] } & \multicolumn{3}{|c|}{ PNU 282987} \\
\hline pmol/hemisphere: & & 0 & 10 & 20 & 0 & 10 & 40 \\
\hline NAc shell & Intake mg/kg & $0.21 \pm 0.03$ & $0.31 \pm 0.02^{\mathrm{a}}$ & $0.34 \pm 0.01^{\mathrm{a}}$ & $0.23 \pm 0.01$ & $0.09 \pm 0.02^{\mathrm{a}}$ & $0.13 \pm 0.04^{\mathrm{a}}$ \\
\hline Anterior cingulate cortex & Nicotine infusions & $5.2 \pm 1.02$ & $8.4 \pm 1.17^{\mathrm{a}}$ & $8.2 \pm 1.16^{\mathrm{a}}$ & $5.8 \pm 0.74$ & $5.4 \pm 0.97$ & $5.75 \pm 1.49$ \\
\hline
\end{tabular}

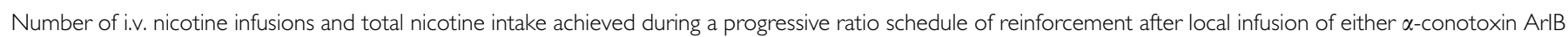

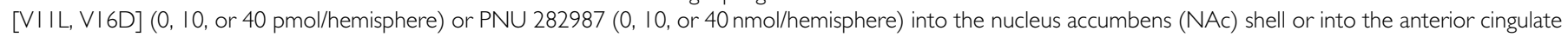

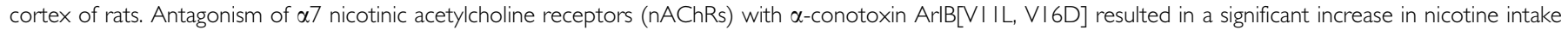
when administered into the NAc shell or the anterior cingulate cortex. In contrast, local infusion of an agonist of nAChRs, PNU 282987, led to significant decreases in nicotine intake, but only when administered into the NAc shell.

andicates significantly different from vehicle infusion $(p<0.05 ; n=4-5$ per group). 
a Anterior Cingulate Cortex
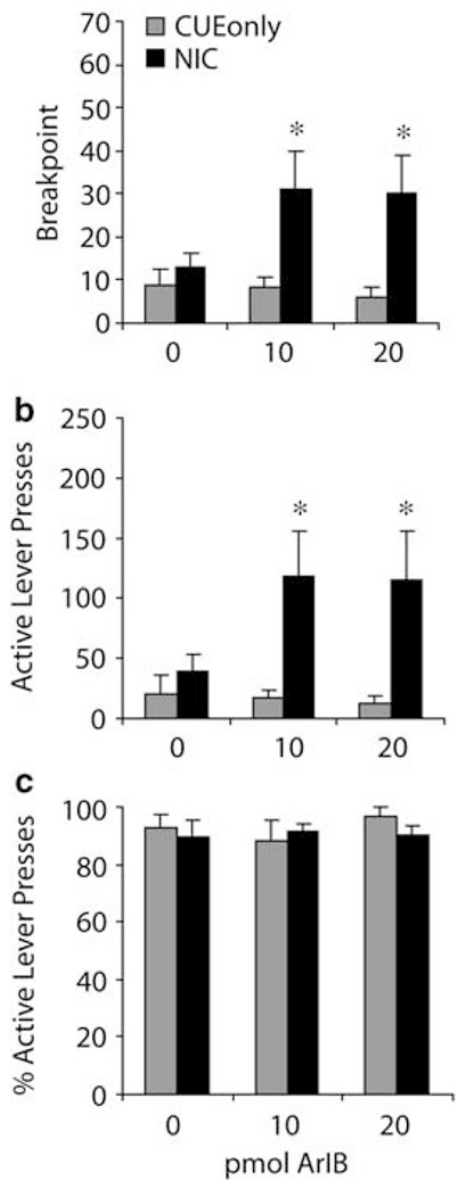

Figure 2 Antagonism of $\alpha 7 \mathrm{nAChRs}$ in the anterior cingulate cortex increases motivation to self-administer nicotine. Local anterior cingulate infusion of ArlB led to an increase in (a) breakpoints and (b) active lever pressing maintained by nicotine during a progressive ratio schedule of reinforcement (NIC; $n=5)$. There was no effect of ArlB infusion on breakpoint or active lever pressing in rats reinforced with light + tone cues but no nicotine (CUEonly; $n=5$ ). (c) Response accuracy as measured by \% active lever pressing was not affected by anterior cingulate infusion of ArlB in NIC or CUEonly rats. *Significantly different from NIC vehicle infusion $(p<0.05)$.

agonist of $\alpha 7$ nAChRs. These results were specific to drug infusion and not due to behavioral variation between NAc shell- and anterior cingulate-infused rats. On the last day of FR1 before PR testing, NIC rats earned a similar number of NIC infusions regardless of whether they had cannulae implanted into the NAc shell (mean $=20.57 \pm$ 3.03 ) or the anterior cingulate cortex (mean $=20.13 \pm 3.35)$. Rats also showed similar levels of NIC intake when infused with vehicle during PR (Table 1). Neuroanatomical reconstructions of guide cannula placement are shown in Figure 4.

\section{DISCUSSION}

This study provides functional evidence that reductions in a7 nAChR activity support motivation for NIC selfadministration. Selective antagonism of $\alpha 7 \mathrm{nAChRs}$ significantly increased the impetus of rats to work for NIC
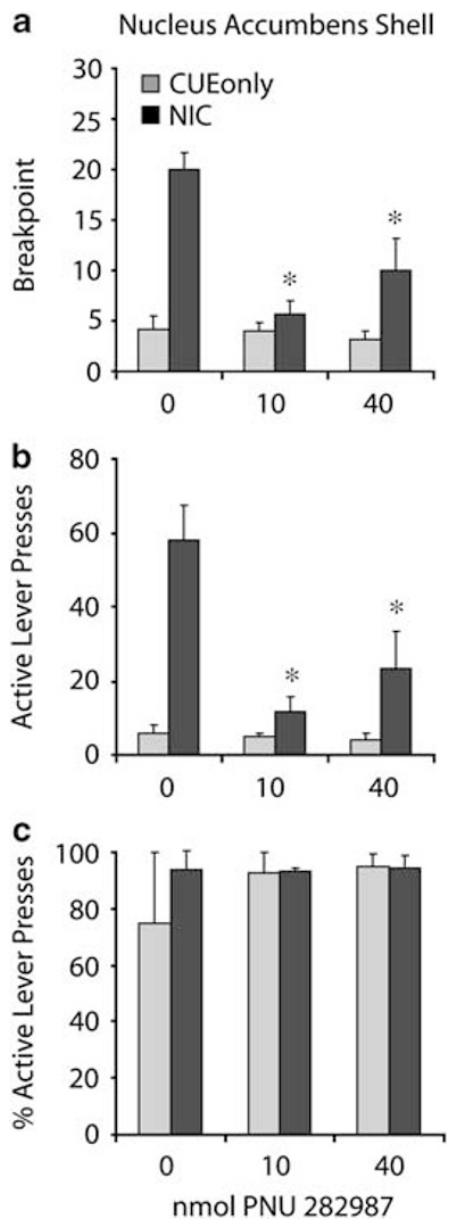

Figure 3 Agonism of $\alpha 7 n A C h R s$ in the NAc shell decreases motivation to self-administer nicotine. Local NAc shell infusion of PNU 282987 led to a significant decrease in (a) breakpoints and (b) active lever pressing maintained by nicotine during a progressive ratio schedule of reinforcement (NIC; $n=4)$. There was no effect of PNU 282987 infusion on breakpoint or active lever pressing in rats reinforced with light + tone cues but no nicotine (CUEonly; $n=4$ ). (c) Response accuracy as measured by \% active lever pressing was not affected by NAc shell infusion of ArIB in NIC or CUEonly rats. *Significantly different from NIC vehicle infusion $(p<0.05)$.

during PR. This effect was observed after drug infusion into the NAc shell, a brain area well-known for its contributions to motivational valence for drugs and natural rewards, as well as after antagonist infusion into the anterior cingulate cortex, a brain area that contributes to addiction, supports behavioral inhibition, and is morphologically compromised in individuals with schizophrenia (Goldman-Rakic, 1994; Guan et al, 1999; Chambers et al, 2001; Marutle et al, 2001; Moss et al, 2009). In contrast, local infusion of a selective $\alpha 7$ nAChR agonist into the NAc shell significantly reduced how hard rats were willing to work for a single infusion of NIC, suggesting that activation of these receptors may promote tobacco cessation. This effect was specific to the NAc shell and not observed in the anterior cingulate cortex. These data suggest that $\alpha 7$ nAChRs are not required for NIC self-administration but rather have a critical role in modulating NIC use.

Together with genetic and postmortem human studies (Freedman et al, 1995, 1997; Guan et al, 1999; Marutle et al, 


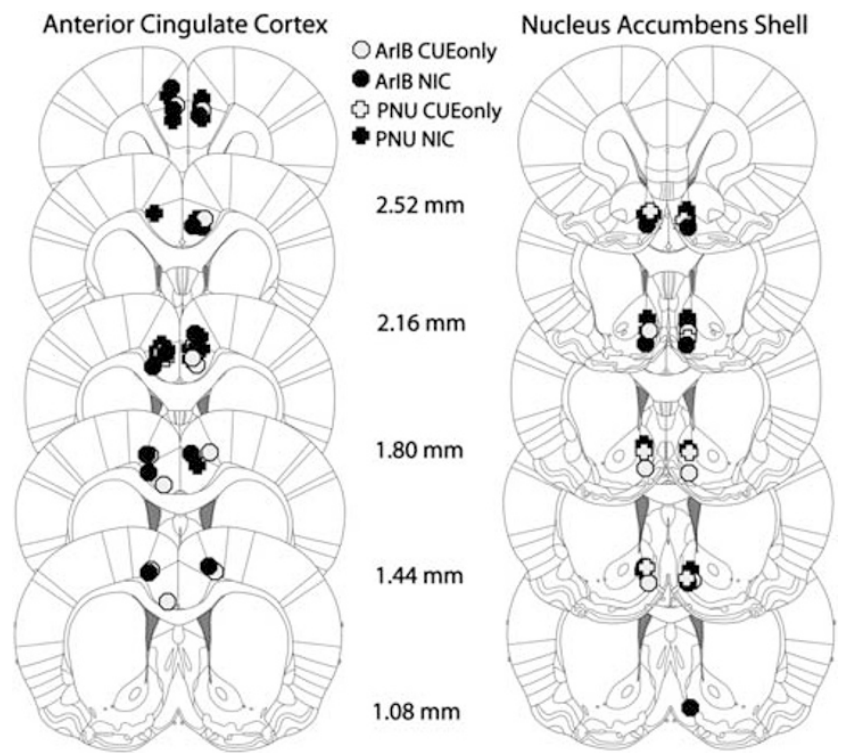

Figure 4 Neuroanatomical reconstructions of guide cannulae placement in the NAc shell and anterior cingulate cortex.

2001; De Luca et al, 2004; Mexal et al, 2010), these findings suggest that some individuals may have a shared vulnerability for tobacco dependence and schizophrenia phenotype. An accumulation of data indicates that $\alpha 7 \mathrm{nAChR}$ expression is compromised in several brain areas of those diagnosed with schizophrenia (Freedman et al, 1997, 2000; Guan et al, 1999; Marutle et al, 2001). This phenotype seems to be due to faulty receptor assembly or trafficking as cigarette smoking results in elevated $\alpha 7 \mathrm{nAChR}$ message and protein yet surface $\alpha 7 \mathrm{nAChRs}$ are decreased as measured by $\alpha$-bungarotoxin binding (Mexal et al, 2010). This could be due to post-translational changes such as reduced palmitoylation of the $\alpha 7 \mathrm{nAChRs}$ (Drisdel et al, 2004; Alexander et al, 2010) and further exacerbated in individuals with a truncated, duplicate $\alpha 7 \mathrm{nAChR}$ gene polymorphism that seems to lead to the formation of faulty $\alpha 7$ nAChRs (Araud et al, 2011; de Lucas-Cerrillo et al, 2011). Other studies suggest that a CHRNA7 intron dinucleotide repeat is positively associated with a significant risk for smoking behavior in those with schizophrenia (De Luca et al, 2004) with evidence for marginal associations for smoking risk in 'healthy' individuals with other point mutations within the CHRNA7 gene (Saccone et al, 2010). These studies in rodents give biological credence to these genetic studies, demonstrating that reductions in $\alpha 7 \mathrm{nAChR}$ function result in significant elevations in motivation to self-administer NIC.

Although there may be some neuroanatomical overlap with $\alpha 7 \mathrm{nAChR}$-associated sensory-gating abnormalities, it is likely that $\alpha 7 \mathrm{nAChR}$ deficits regulate smoking and schizophrenia phenotype through different neuroanatomical pathways. The $\alpha 7 \mathrm{nAChRs}$ are enriched in deep layers of the cortex that are connected to the sensory thalamus, perhaps accounting for the sensory-gating deficits that are associated with this genotype (Clarke et al, 1985; LuntzLeybman et al, 1992; Stevens et al, 1996; Breese et al, 1997; Freedman et al, 1997; Bodnar et al, 2005; Hajos et al, 2005;
Leonard et al, 2007). $\alpha$-Bungarotoxin-binding studies show that $\alpha 7 \mathrm{nAChR}$ expression is higher in the cingulate and more ubiquitously expressed across layers than in other cortical regions (Marutle et al, 2001). Individuals diagnosed with schizophrenia have a $50 \%$ reduction in cingulate expression of $\alpha 7 \mathrm{nAChRs}$ (Marutle et al, 2001). We observed that antagonism of $\alpha 7 \mathrm{nAChRs}$ in the anterior cingulate cortex was sufficient to increase motivation to selfadminister NIC. Human studies have revealed that deficits in prefrontal cortex function are also correlated with failed quit attempts in schizophrenic smokers (Moss et al, 2009). We saw a similar effect of blocking $\alpha 7 \mathrm{nAChRs}$ in the NAc shell; local administration of an $\alpha 7 \mathrm{nAChR}$ antagonist significantly increased NIC self-administration during PR. In contrast, application of an $\alpha 7 \mathrm{nAChR}$ agonist effectively reduced NIC administration but only when administered into the NAc shell, perhaps due to the unique influence of dopamine signaling on $\alpha 7 \mathrm{nAChR}$ activity at this locus $v s$ the predominant basal ganglia innervation that supports activation of $\alpha 7 \mathrm{nAChRs}$ in the anterior cingulate cortex (Thomsen et al, 2010). These findings warrant further study into the expression of $\alpha 7 \mathrm{nAChRs}$ in the NAc shell of smokers and in individuals diagnosed with schizophrenia.

Previous preclinical studies exploring the role of $\alpha 7$ nAChRs in NIC reinforcement have returned equivocal results. Systemic administration of the $\alpha 7$ antagonist methylcoconitine (MLA) resulted in significant reductions in self-administration of NIC during an FR1 schedule of reinforcement (Markou and Paterson, 2001) at 3.8 and $7.9 \mathrm{mg} / \mathrm{kg}$ MLA, whereas others have reported no effect of a similar dosing regimen on self-administration when rats had a 2 day wash-out period between MLA dosings (Grottick et al, 2000). Although it is not clear what concentrations would be achieved in the brain at these doses, in vitro studies have shown that higher concentrations of MLA antagonize $\alpha 6^{\star}$ AChRs (Mogg et al, 2002), as well as $\alpha 7$ nAChRs. Recent reports show that activation of $\alpha 6^{*}$ nAChRs in the VTA and NAc shell are critical for acquisition and maintenance of NIC self-administration (Pons et al, 2008; Brunzell et al, 2010; Gotti et al, 2010); thus, effects with high doses of MLA may have been due to off-target antagonism of $\alpha 6^{\star} n A C h R s$. The ArIB compound used in this study has $>500$-fold selectivity for $\alpha 7 \mathrm{nAChRs}$ over other nAChR subtypes (Whiteaker et al, 2008). In contrast, $\alpha$-conotoxin MII is an antagonist of $\alpha 6 \beta 2^{*}$ nAChRs. NAc infusion of MII using the same paradigm as that used in this study shows the reverse effect of ArIB. That is, blockade of $\alpha 6 \beta 2^{*}$ nAChRs by $\alpha$-conotoxin MII dose dependently decreased breakpoints and number of infusions earned (Brunzell et al, 2010), whereas antagonism of $\alpha 7 \mathrm{nAChRs}$ by ArIB increased NIC self-administration during PR, a schedule of reinforcement that is considered to measure motivation to self-administer drugs of abuse (Arnold and Roberts, 1997). Moreover, in contrast to effects of ArIB, we further observed that local administration of a selective $\alpha 7 \mathrm{nAChR}$ agonist into the NAc shell decreased NIC self-administration during PR. Thus, $\alpha 6 \beta 2^{*}$ nAChRs and $\alpha 7$ nAChRs in the NAc shell seem to have an opposing effect on NIC self-administration. Activation of $\alpha 6 \beta 2{ }^{*}$ nAChRs supports NIC self-administration, whereas activation of $\alpha 7$ nAChRs impedes motivation to self-administer the drug. 
Rather than having an essential role in NIC selfadministration, our findings suggest that $\alpha 7 \mathrm{nAChRs}$ modulate NIC administration behavior. This hypothesis is supported by studies that show that mice with $\alpha 7$ subunit null mutations show normal NIC reward as measured by NIC conditioned place preference and acquisition of tail vein NIC administration (Walters et al, 2006; Pons et al, 2008). Other reports suggest that $\alpha 7$ may contribute to NIC intake after repeated exposure as measured by a reduction in NIC:water ratio during a 2-bottle choice paradigm (Levin et al, 2009). However, it is not clear in these latter studies if mice favor less NIC over time, or if over time, $\alpha 7$ knockout mice need less drug to achieve the desired effects of NIC. Our studies performed during PR indicate that local antagonism of $\alpha 7 \mathrm{nAChRs}$ in the NAc shell and anterior cingulate cortex increased the motivation of rats to work for an intravenous NIC reinforcer. Given the low affinity of the $\alpha 7 \mathrm{nAChRs}$ for NIC and the limited number of NIC infusions achieved during the demanding PR schedule of reinforcement, it is likely that the effect of ArIB was due to blockade of an endogenous cholinergic signal and not due to blockade of NIC action at $\alpha 7$ nAChRs (McGehee and Role, 1995; Mansvelder et al, 2002; Wooltorton et al, 2003; Papke et al, 2010). Unlike the high-affinity $\beta 2^{\star}$ nAChRs, activation of $\alpha 7$ nAChRs on DA terminals is not critical for NIC-stimulated striatal DA release (Champtiaux and Changeux, 2004; Salminen et al, 2004), and a recent microdialysis study showed that systemic administration of NIC results in elevated, persistent release of DA in the NAc shell of $\alpha 7$ nAChR knockout mice compared with wild-type mice on the same background (Besson et al, 2011). Hence, ACh activity at $\alpha 7 \mathrm{nAChRs}$ in the NAc shell and anterior cingulate cortex may curb NIC self-administration behavior through modulation of DA release. These findings have implications for individuals with schizophrenia who have a poverty of $\alpha 7$ nAChRs in the cingulate cortex (Marutle et al, 2001) that may render them vulnerable to heavy tobacco use. Whereas these findings resemble recent reports showing that $\alpha 5 \mathrm{nAChR}$ subunit knockout mice administer more NIC than their wild-type counterparts during FR schedules of reinforcement (Fowler et al, 2011), we make a distinction that the present observations do not reflect a decrease in the aversive effects of NIC after $\alpha 7 \mathrm{nAChR}$ antagonism. In general, NIC becomes aversive at high doses. During PR, rats in this study received approximately one-third of the NIC that they demonstrated they were willing to ingest during the FR1 schedule of reinforcement (Table 1).

It appears from our studies that activation of $\alpha 7 \mathrm{nAChRs}$ by the endogenous neurotransmitter ACh counters the behavioral effects of NIC at the high-affinity nAChRs. It is not clear whether most smokers achieve brain levels of NIC that are sufficient to activate the lower-affinity $\alpha 7 \mathrm{nAChRs}$, but recent work using a ${ }^{11} \mathrm{C}$ NIC tracer estimates that heavy smokers, such as those with schizophrenia (de Leon, 1996), may achieve as high as $700 \mathrm{nM}$ NIC in the brain after a smoking episode and that brain levels of NIC accumulate during the day (Rose et al, 2010). In vitro studies suggest that $1-10 \mu \mathrm{M}$ NIC is sufficient to bind and activate $\alpha 7$ nAChRs and quickly after activation by NIC, nAChRs undergo a period of desensitization (Lester and Dani, 1995; McGehee et al, 1995; Mansvelder et al, 2002; Uteshev et al, 2002; Wooltorton et al, 2003; Papke et al, 2009). These findings suggest that motivation to self-administer NIC could be significantly elevated by desensitization of $\alpha 7$ nAChRs in the NAc shell or anterior cingulate cortex. This effect could be exaggerated in schizophrenic smokers who already have a deficit of $\alpha 7 \mathrm{nAChRs}$ in the cingulate cortex (Marutle et al, 2001).

Recent studies have identified $\alpha 7 \mathrm{nAChRs}$ as therapeutic targets for improving cognition, memory, and gating deficits in schizophrenia (Bodnar et al, 2005; Olincy et al, 2006; Bitner et al, 2007; Freedman et al, 2008; Rezvani et al, 2009; Hajos and Rogers, 2010; Marquis et al, 2011). This study in rats suggests that activation of $\alpha 7 \mathrm{nAChRs}$ may have the added benefit of curbing motivation to smoke cigarettes. It is of interest to note that the US Food and Drug Administration approved smoking cessation drug, varenicline, although marketed as an $\alpha 4 \beta 2 \mathrm{nAChR}$ partial agonist, also has full agonist properties at $\alpha 7 \mathrm{nAChRs}$ (Mihalak et al, 2006). The findings of this study suggest that varenicline may exert some of its therapeutic effects through activation of $\alpha 7 \mathrm{nAChRs}$.

In summary, these data demonstrate that reductions in $\alpha 7$ $\mathrm{nAChR}$ function promote NIC use. These findings expand on previous data which suggest that the CHRNA7 genotype is associated with tobacco dependence and identify low expression of $\alpha 7 \mathrm{nAChRs}$ as a potential mechanism by which individuals express a shared vulnerability to tobacco use and schizophrenia. These findings further identify activation of $\alpha 7 \mathrm{nAChRs}$ as a strategy that should be further explored for treatment of tobacco addiction.

\section{ACKNOWLEDGEMENTS}

This study was supported by a Virginia Foundation for Healthy Youth grant 8520667 and NIH grants DA031289 and DA023114 to DHB and MH53631 and GM48677 to JMM. We thank Karen Boschen, William Renzulli, Jennifer Lee, and Lauren Thompson for their technical assistance with these studies.

\section{DISCLOSURE}

Virginia Commonwealth University holds an invention patent with DH Brunzell listed as an inventor 'Alpha7 nicotinic acetylcholine receptor (nAChR) agonism to promote smoking cessation' VCU BRU-11-008F, which is based on the findings presented within this paper. JM McIntosh has received funding from Targacept for projects unrelated to this work.

\section{REFERENCES}

Alexander JK, Govind AP, Drisdel RC, Blanton MP, Vallejo Y, Lam TT et al. (2010). Palmitoylation of nicotinic acetylcholine receptors. J Mol Neurosci 40: 12-20.

Araud T, Graw S, Berger R, Lee M, Neveu E, Bertrand D et al. (2011). The chimeric gene CHRFAM7A, a partial duplication of the CHRNA7 gene, is a dominant negative regulator of alpha7*nAChR function. Biochem Pharmacol 82: 904-914.

Arnold JM, Roberts DC (1997). A critique of fixed and progressive ratio schedules used to examine the neural substrates of drug reinforcement. Pharmacol Biochem Behav 57: 441-447.

Besson M, David V, Baudonnat M, Cazala P, Guilloux JP, Reperant C et al. (2011). Alpha7-nicotinic receptors modulate nicotine- 
induced reinforcement and extracellular dopamine outflow in the mesolimbic system in mice. Psychopharmacology (Berl); e-pub ahead of print 8 September 2011.

Bitner RS, Bunnelle WH, Anderson DJ, Briggs CA, Buccafusco J, Curzon $\mathrm{P}$ et al. (2007). Broad-spectrum efficacy across cognitive domains by alpha7 nicotinic acetylcholine receptor agonism correlates with activation of ERK1/2 and CREB phosphorylation pathways. J Neurosci 27: 10578-10587.

Bodnar AL, Cortes-Burgos LA, Cook KK, Dinh DM, Groppi VE, Hajos M et al. (2005). Discovery and structure-activity relationship of quinuclidine benzamides as agonists of alpha7 nicotinic acetylcholine receptors. J Med Chem 48: 905-908.

Breese CR, Adams C, Logel J, Drebing C, Rollins Y, Barnhart M et al. (1997). Comparison of the regional expression of nicotinic acetylcholine receptor alpha7 mRNA and [125I]-alpha-bungarotoxin binding in human postmortem brain. J Comp Neurol 387: 385-398.

Brunzell DH, Boschen KE, Hendrick ES, Beardsley PM, McIntosh JM (2010). Alpha-conotoxin MII-sensitive nicotinic acetylcholine receptors in the nucleus accumbens shell regulate progressive ratio responding maintained by nicotine. Neuropsychopharmacology 35: 665-673.

Brunzell DH, Mineur YS, Neve RL, Picciotto MR (2009). Nucleus accumbens CREB activity is necessary for nicotine conditioned place preference. Neuropsychopharmacology 34: 1993-2001.

Caggiula AR, Donny EC, Chaudhri N, Perkins KA, Evans-Martin FF, Sved AF (2002). Importance of nonpharmacological factors in nicotine self-administration. Physiol Behav 77: 683-687.

Castner SA, Smagin GN, Piser TM, Wang Y, Smith JS, Christian EP et al. (2011). Immediate and sustained improvements in working memory after selective stimulation of alpha7 nicotinic acetylcholine receptors. Biol Psychiatry 69: 12-18.

Chambers RA, Krystal JH, Self DW (2001). A neurobiological basis for substance abuse comorbidity in schizophrenia. Biol Psychiatry 50: 71-83.

Champtiaux N, Changeux JP (2004). Knockout and knockin mice to investigate the role of nicotinic receptors in the central nervous system. Prog Brain Res 145: 235-251.

Clarke PB, Schwartz RD, Paul SM, Pert CB, Pert A (1985). Nicotinic binding in rat brain: autoradiographic comparison of $[3 \mathrm{H}]$ acetylcholine, [3H]nicotine, and [125I]-alpha-bungarotoxin. J Neurosci 5: 1307-1315.

Court JA, Martin-Ruiz C, Graham A, Perry E (2000). Nicotinic receptors in human brain: topography and pathology. J Chem Neuroanat 20: 281-298.

D’Souza MS, Markou A (2011). Schizophrenia and tobacco smoking comorbidity: nAChR agonists in the treatment of schizophrenia-associated cognitive deficits. Neuropharmacology.

de Leon J (1996). Smoking and vulnerability for schizophrenia. Schizophr Bull 22: 405-409.

De Luca V, Wong AH, Muller DJ, Wong GW, Tyndale RF, Kennedy JL (2004). Evidence of association between smoking and alpha7 nicotinic receptor subunit gene in schizophrenia patients. Neuropsychopharmacology 29: 1522-1526.

de Lucas-Cerrillo AM, Maldifassi MC, Arnalich F, Renart J, Atienza G, Serantes R et al. (2011). Function of partially duplicated human alpha7 nicotinic receptor subunit CHRFAM7A gene: potential implications for the cholinergic anti-inflammatory response. J Biol Chem 286: 594-606.

Drisdel RC, Manzana E, Green WN (2004). The role of palmitoylation in functional expression of nicotinic alpha7 receptors. J Neurosci 24: 10502-10510.

Elliott KJ, Ellis SB, Berckhan KJ, Urrutia A, Chavez-Noriega LE, Johnson EC et al. (1996). Comparative structure of human neuronal alpha 2-alpha 7 and beta 2-beta 4 nicotinic acetylcholine receptor subunits and functional expression of the alpha 2, alpha 3 , alpha 4 , alpha 7 , beta 2 , and beta 4 subunits. J Mol Neurosci 7: 217-228.
Fowler CD, Lu Q, Johnson PM, Marks MJ, Kenny PJ (2011). Habenular alpha5 nicotinic receptor subunit signalling controls nicotine intake. Nature 471: 597-601.

Freedman R, Adams CE, Leonard S (2000). The alpha7-nicotinic acetylcholine receptor and the pathology of hippocampal interneurons in schizophrenia. J Chem Neuroanat 20: 299-306.

Freedman R, Hall M, Adler LE, Leonard S (1995). Evidence in postmortem brain tissue for decreased numbers of hippocampal nicotinic receptors in schizophrenia. Biol Psychiatry 38: 22-33.

Freedman R, Coon H, Myles-Worsley M, Orr-Urtreger A, Olincy A, Davis A et al. (1997). Linkage of a neurophysiological deficit in schizophrenia to a chromosome 15 locus. Proc Natl Acad Sci USA 94: 587-592.

Freedman R, Olincy A, Buchanan RW, Harris JG, Gold JM, Johnson L et al. (2008). Initial phase 2 trial of a nicotinic agonist in schizophrenia. Am J Psychiatry 165: 1040-1047.

Glassman AH (1993). Cigarette smoking: implications for psychiatric illness. Am J Psychiatry 150: 546-553.

Goldman-Rakic PS (1994). Working memory dysfunction in schizophrenia. J Neuropsychiatry Clin Neurosci 6: 348-357.

Gotti C, Guiducci S, Tedesco V, Corbioli S, Zanetti L, Moretti M et al. (2010). Nicotinic acetylcholine receptors in the mesolimbic pathway: primary role of ventral tegmental area alpha6beta2* receptors in mediating systemic nicotine effects on dopamine release, locomotion, and reinforcement. J Neurosci 30: 5311-5325.

Grottick AJ, Trube G, Corrigall WA, Huwyler J, Malherbe P, Wyler $\mathrm{R}$ et al. (2000). Evidence that nicotinic alpha(7) receptors are not involved in the hyperlocomotor and rewarding effects of nicotine. J Pharmacol Exp Ther 294: 1112-1119.

Guan ZZ, Zhang X, Blennow K, Nordberg A (1999). Decreased protein level of nicotinic receptor alpha7 subunit in the frontal cortex from schizophrenic brain. Neuroreport 10: 1779-1782.

Hajos M, Rogers BN (2010). Targeting alpha7 nicotinic acetylcholine receptors in the treatment of schizophrenia. Curr Pharm Des 16: $538-554$.

Hajos M, Hurst RS, Hoffmann WE, Krause M, Wall TM, Higdon NR et al. (2005). The selective alpha7 nicotinic acetylcholine receptor agonist PNU-282987 [N-[(3R)-1-Azabicyclo[2.2.2]oct3-yl]-4-chlorobenzamide hydrochloride] enhances GABAergic synaptic activity in brain slices and restores auditory gating deficits in anesthetized rats. J Pharmacol Exp Ther 312: $1213-1222$.

Hughes JR, Hatsukami DK, Mitchell JE, Dahlgren LA (1986). Prevalence of smoking among psychiatric outpatients. Am J Psychiatry 143: 993-997.

Kalman D, Morissette SB, George TP (2005). Co-morbidity of smoking in patients with psychiatric and substance use disorders. Am J Addict 14: 106-123.

Leonard S, Mexal S, Freedman R (2007). Smoking, genetics and schizophrenia: evidence for self medication. J Dual Diagn 3: 43-59.

Leonard S, Adams C, Breese CR, Adler LE, Bickford P, Byerley W et al. (1996). Nicotinic receptor function in schizophrenia. Schizophr Bull 22: 431-445.

Leonard S, Breese C, Adams C, Benhammou K, Gault J, Stevens K et al. (2000). Smoking and schizophrenia: abnormal nicotinic receptor expression. Eur J Pharmacol 393: 237-242.

Leonard S, Gault J, Adams C, Breese CR, Rollins Y, Adler LE et al. (1998). Nicotinic receptors, smoking and schizophrenia. Restor Neurol Neurosci 12: 195-201.

Leonard S, Gault J, Hopkins J, Logel J, Vianzon R, Short M et al. (2002). Association of promoter variants in the alpha7 nicotinic acetylcholine receptor subunit gene with an inhibitory deficit found in schizophrenia. Arch Gen Psychiatry 59: 1085-1096.

Lester RA, Dani JA (1995). Acetylcholine receptor desensitization induced by nicotine in rat medial habenula neurons. J Neurophysiol 74: 195-206. 
Levin ED, Rezvani AH (2007). Nicotinic interactions with antipsychotic drugs, models of schizophrenia and impacts on cognitive function. Biochem Pharmacol 74: 1182-1191.

Levin ED, Petro A, Rezvani AH, Pollard N, Christopher NC, Strauss $\mathrm{M}$ et al. (2009). Nicotinic alpha7- or beta2-containing receptor knockout: effects on radial-arm maze learning and long-term nicotine consumption in mice. Behav Brain Res 196: 207-213.

Luntz-Leybman V, Bickford PC, Freedman R (1992). Cholinergic gating of response to auditory stimuli in rat hippocampus. Brain Res 587: 130-136.

Mansvelder HD, Keath JR, McGehee DS (2002). Synaptic mechanisms underlie nicotine-induced excitability of brain reward areas. Neuron 33: 905-919.

Markou A, Paterson NE (2001). The nicotinic antagonist methyllycaconitine has differential effects on nicotine selfadministration and nicotine withdrawal in the rat. Nicotine Tob Res 3: 361-373.

Marquis KL, Comery TA, Jow F, Navarra RL, Grauer SM, Pulicicchio C et al. (2011). Preclinical assessment of an adjunctive treatment approach for cognitive impairment associated with schizophrenia using the alpha7 nicotinic acetylcholine receptor agonist WYE-103914/SEN34625. Psychopharmacology (Berl) 218: 635-647.

Marutle A, Zhang X, Court J, Piggott M, Johnson M, Perry R et al. (2001). Laminar distribution of nicotinic receptor subtypes in cortical regions in schizophrenia. J Chem Neuroanat 22: $115-126$.

McGehee DS, Heath MJ, Gelber S, Devay P, Role LW (1995). Nicotine enhancement of fast excitatory synaptic transmission in CNS by presynaptic receptors. Science 269: 1692-1696.

McGehee DS, Role LW (1995). Physiological diversity of nicotinic acetylcholine receptors expressed by vertebrate neurons. Annu Rev Physiol 57: 521-546.

McKee SA, Weinberger AH, Harrison EL, Coppola S, George TP (2009). Effects of the nicotinic receptor antagonist mecamylamine on ad-lib smoking behavior, topography, and nicotine levels in smokers with and without schizophrenia: a preliminary study. Schizophr Res 115: 317-324.

Mexal S, Berger R, Logel J, Ross RG, Freedman R, Leonard S (2010). Differential regulation of alpha7 nicotinic receptor gene (CHRNA7) expression in schizophrenic smokers. J Mol Neurosci 40: 185-195.

Mihalak KB, Carroll FI, Luetje CW (2006). Varenicline is a partial agonist at alpha4beta2 and a full agonist at alpha7 neuronal nicotinic receptors. Mol Pharmacol 70: 801-805.

Mogg AJ, Whiteaker P, McIntosh JM, Marks M, Collins AC, Wonnacott S (2002). Methyllycaconitine is a potent antagonist of alpha-conotoxin-MII-sensitive presynaptic nicotinic acetylcholine receptors in rat striatum. J Pharmacol Exp Ther 302: 197-204.

Moss TG, Sacco KA, Allen TM, Weinberger AH, Vessicchio JC, George TP (2009). Prefrontal cognitive dysfunction is associated with tobacco dependence treatment failure in smokers with schizophrenia. Drug Alcohol Depend 104: 94-99.

Olincy A, Young DA, Freedman R (1997). Increased levels of the nicotine metabolite cotinine in schizophrenic smokers compared to other smokers. Biol Psychiatry 42: 1-5.

Olincy A, Harris JG, Johnson LL, Pender V, Kongs S, Allensworth $\mathrm{D}$ et al. (2006). Proof-of-concept trial of an alpha7 nicotinic agonist in schizophrenia. Arch Gen Psychiatry 63: 630-638.

Olsen CM, Winder DG (2009). Operant sensation seeking engages similar neural substrates to operant drug seeking in C57 mice. Neuropsychopharmacology 34: 1685-1694.

Papke RL, Kem WR, Soti F, Lopez-Hernandez GY, Horenstein NA (2009). Activation and desensitization of nicotinic alpha7-type acetylcholine receptors by benzylidene anabaseines and nicotine. J Pharmacol Exp Ther 329: 791-807.
Papke RL, Wecker L, Stitzel JA (2010). Activation and inhibition of mouse muscle and neuronal nicotinic acetylcholine receptors expressed in Xenopus oocytes. J Pharmacol Exp Ther 333: 501-518.

Pons S, Fattore L, Cossu G, Tolu S, Porcu E, McIntosh JM et al. (2008). Crucial role of alpha4 and alpha6 nicotinic acetylcholine receptor subunits from ventral tegmental area in systemic nicotine self-administration. J Neurosci 28: 12318-12327.

Rezvani AH, Kholdebarin E, Brucato FH, Callahan PM, Lowe DA, Levin ED (2009). Effect of R3487/MEM3454, a novel nicotinic alpha7 receptor partial agonist and 5-HT3 antagonist on sustained attention in rats. Prog Neuropsychopharmacol Biol Psychiatry 33: 269-275.

Rose JE, Mukhin AG, Lokitz SJ, Turkington TG, Herskovic J, Behm FM et al. (2010). Kinetics of brain nicotine accumulation in dependent and nondependent smokers assessed with PET and cigarettes containing 11C-nicotine. Proc Natl Acad Sci USA 107: 5190-5195.

Sacco KA, Termine A, Seyal A, Dudas MM, Vessicchio JC, Krishnan-Sarin S et al. (2005). Effects of cigarette smoking on spatial working memory and attentional deficits in schizophrenia: involvement of nicotinic receptor mechanisms. Arch Gen Psychiatry 62: 649-659.

Saccone NL, Schwantes-An TH, Wang JC, Grucza RA, Breslau N, Hatsukami D et al. (2010). Multiple cholinergic nicotinic receptor genes affect nicotine dependence risk in African and European Americans. Genes Brain Behav 9: 741-750.

Salminen O, Murphy KL, McIntosh JM, Drago J, Marks MJ, Collins AC et al. (2004). Subunit composition and pharmacology of two classes of striatal presynaptic nicotinic acetylcholine receptors mediating dopamine release in mice. Mol Pharmacol 65: 15261535.

Séguéla P, Wadiche J, Dineley-Miller K, Dani JA, Patrick JW (1993). Molecular cloning, functional properties, and distribution of rat brain alpha 7: a nicotinic cation channel highly permeable to calcium. J Neurosci 13: 596-604.

Stassen HH, Bridler R, Hagele S, Hergersberg M, Mehmann B, Schinzel A et al. (2000). Schizophrenia and smoking: evidence for a common neurobiological basis? Am J Med Genet 96: 173-177.

Stephens SH, Logel J, Barton A, Franks A, Schultz J, Short M et al. (2009). Association of the $5^{\prime}$-upstream regulatory region of the alpha7 nicotinic acetylcholine receptor subunit gene (CHRNA7) with schizophrenia. Schizophr Res 109: 102-112.

Stevens KE, Kem WR, Mahnir VM, Freedman R (1998). Selective alpha7-nicotinic agonists normalize inhibition of auditory response in DBA mice. Psychopharmacology (Berl) 136: 320-327.

Stevens KE, Freedman R, Collins AC, Hall M, Leonard S, Marks MJ et al. (1996). Genetic correlation of inhibitory gating of hippocampal auditory evoked response and alpha-bungarotoxin-binding nicotinic cholinergic receptors in inbred mouse strains. Neuropsychopharmacology 15: 152-162.

Thomsen MS, Christensen DZ, Hansen HH, Redrobe JP, Mikkelsen JD (2009). Alpha(7) nicotinic acetylcholine receptor activation prevents behavioral and molecular changes induced by repeated phencyclidine treatment. Neuropharmacology 56: 1001-1009.

Thomsen MS, Hay-Schmidt A, Hansen HH, Mikkelsen JD (2010). Distinct neural pathways mediate alpha7 nicotinic acetylcholine receptor-dependent activation of the forebrain. Cereb Cortex 20: 2092-2102.

Tidey JW, Rohsenow DJ, Kaplan GB, Swift RM (2005). Cigarette smoking topography in smokers with schizophrenia and matched non-psychiatric controls. Drug Alcohol Depend 80: 259-265.

Uteshev VV, Meyer EM, Papke RL (2002). Activation and inhibition of native neuronal alpha-bungarotoxin-sensitive nicotinic ACh receptors. Brain Res 948: 33-46. 
Walters CL, Brown S, Changeux JP, Martin B, Damaj MI (2006). The beta2 but not alpha7 subunit of the nicotinic acetylcholine receptor is required for nicotine-conditioned place preference in mice. Psychopharmacology (Berl) 184: 339-344.

Whiteaker P, Marks MJ, Christensen S, Dowell C, Collins AC, McIntosh JM (2008). Synthesis and characterization of 125I-alphaconotoxin ArIB[V11 L;V16A], a selective alpha7 nicotinic acetylcholine receptor antagonist. J Pharmacol Exp Ther 325: 910-919.

Whiteaker P, Christensen S, Yoshikami D, Dowell C, Watkins M, Gulyas J et al. (2007). Discovery, synthesis, and structure activity of a highly selective alpha7 nicotinic acetylcholine receptor antagonist. Biochemistry 46: 6628-6638.

Williams JM, Gandhi KK, Steinberg ML, Foulds J, Ziedonis DM, Benowitz NL (2007). Higher nicotine and carbon monoxide levels in menthol cigarette smokers with and without schizophrenia. Nicotine Tob Res 9: 873-881.
Williams JM, Ziedonis DM, Abanyie F, Steinberg ML, Foulds J, Benowitz NL (2005). Increased nicotine and cotinine levels in smokers with schizophrenia and schizoaffective disorder is not a metabolic effect. Schizophr Res 79: 323-335.

Wooltorton JR, Pidoplichko VI, Broide RS, Dani JA (2003). Differential desensitization and distribution of nicotinic acetylcholine receptor subtypes in midbrain dopamine areas. $J$ Neurosci 23: 3176-3185.

(c) This work is licensed under the Creative

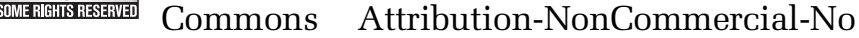
Derivative Works 3.0 Unported License. To view a copy of this license, visit http://creativecommons.org/ licenses/by-nc-nd/3.0/ 